\title{
Face and self-presentation in spoken L2 discourse: Renewing the research agenda in interlanguage pragmatics
}

DORIS DIPPOLD

\section{Abstract}

This paper introduces a more nuanced view of face and facework than the commonly used frameworks in interlanguage pragmatics. It argues that ILP not only prioritizes research on the expression of politeness in the L2 and the acquisition of politeness strategies, but that the field also does that in an extremely decontextualized manner that takes little account of the situatedness of linguistic discourse. Moreover, the paper suggests that existing accounts of face and facework with their focus on politeness alone may not be sufficient to capture speakers' projection of other aspects of self-hood, i.e. the social identities and/or attributes that they want to foreground and be attributed with in particular situations.

By analyzing an argumentative conversation of two L2 learners of German, the paper shows different ways in which self-presentation is performed, e.g., by the way speakers organize their turns, the way they modalize their discourse, and the way they use markers of reference and identity. It then argues that the field of interlanguage pragmatic should move away from its focus on politeness in a limited set of speech acts and focus also on self-presentation.

\section{Introduction}

In a paper on pragmatic strategies for the expression of rudeness, Beebe (1995) wrote:

In the linguistic literature, the emphasis has been on the intention of politeness and the accidental failure to convey politeness. What a beautiful world! But is it the world we live in? [...] It is high time we focused on rudeness. It is the language that ESL and native-speaking students have to deal with in the real world. They have to learn to get power/control and express negative feelings - but in appropriate ways. This is the neglected side of communicative competence. (167) 


\section{Doris Dippold}

Despite the fact that this quote is not a very recent one, I have chosen to use it as introduction to this paper, as I believe that it is still valid today. First, the large majority of studies in interlanguage pragmatics still promotes-despite the fact that theoretical frameworks have moved on to include impoliteness or rudeness (Culpeper 1996; Kienpointner 1997; Harris 2001; Culpeper et al. 2003) - a limited view of facework, in which the emphasis is on strategies for mitigating/avoiding face-threatening acts (FTAs) to the hearer. In addition to this, interlanguage pragmatics generally investigates second-order-politeness rather than first-order-politeness. This means that hearer evaluation of what is being said does not play any role in most investigations in interlanguage pragmatics, as do speakers' motives behind particular strategies.

This paper starts by reviewing the literature that has influenced our perspective on face, politeness, and related concepts, including some of the criticism that has been brought forward against these frameworks. It argues that none of these frameworks truly captures what I see to be an important aspect of all conversational interaction: speakers' selfpresentation, the projection of a self-image based on particular social roles or identities and qualities that speakers want have attributed to themselves. This claim is then illustrated with data from a research project on the development of facework strategies in L2 German argumentative discourse. The paper finishes with a discussion of the data and the implications for L2 pedagogy in the area of pragmatics.

\section{Face, politeness and self-presentation}

\subsection{Goffman's face}

Frameworks based on "face" and, derived from it, "politeness", have proven extremely fruitful for both cross-cultural and interlanguage pragmatics for some time and there is barely a piece of research in those fields that does not mention face. When discussing face and facework in crosscultural environments and interlanguage, reference is often made to what is, still — at least in Western schools of thought - the most popular definition of face by Goffman (1967):

The term face may be defined as the positive social value a person effectively claims for himself by the line others assume he has taken during a particular contact. Face is an image of self delineated in terms of approved social attributesalbeit an image that others may share, as when a person makes a good showing for his profession or religion by making a good showing for himself. (5) 
The question of the extent to which face is an individual or social phenomenon and is related to identity has, in the past, been fiercely debated. Arundale (2005) for example argues that "face [...] is not equivalent with identity. Both relationships and identity arise and sustained in communication, but a relationship and hence face, is a dyadic phenomenon, whereas identity is an individual (and much broader phenomenon)." In contrast however, Tracy (1990: 210), though also describing face as a social phenomenon that is "created through the communicative moves of interactants," equates face with particular socially situated identities that people bring into interactions, identities that can be enacted, supported or challenged.

I return to this debate later. Initially, I feel that it is important to point to some specific issues relating Goffman's notion of face that warrant attention.

First, Goffman's definition suggests that face is not an entirely social phenomenon, but involving some degree of active self-presentation. $\mathrm{He}$ explicitly talks of a "self-image", that is "claimed". Although, in the end, this image needs to be bestowed on a speaker by others present, as a result of what the person projects, face is a conglomerate of the selfimage speakers want to present to the outside world and the image that is constructed of them by others.

Second, Goffman sees the self-image claimed by speakers to be associated with particular social attributes. Although he does not mention any examples for these attributes, they do not appear to be limited or restricted in any way. Hence, there are many possible options for the kind of attributions speakers want to have ascribed to themselves. Speakers could want to be attributed with being polite, but a very wide range of other adjectives can be used to extend this list of possible attributions (e.g. nice, persistent, flexible, etc.).

Finally, the situational contingency and social identity aspect of 'face' is something that is clearly central to Goffman's framework. Goffman mentions profession and religion, but a range of other social roles and identities is also imaginable. According to Goffman, speakers follow a "line" (5) that prescribes a certain kind of behavior expected from them, a line which tends to be "of a legitimate institutionalized kind" (7), i.e., is again context-bound and tied to institutional procedures.

\subsection{Brown and Levinson's face}

Most theoretical frameworks guiding research in interlanguage pragmatics are rooted in Brown and Levinson (1987), whose famous theory of face and politeness presents the notion of face to be derived from Goffman 
as well as English folk terms such as "losing face". Two facets of face are distinguished (Brown and Levinson 1987: 61).

- Negative face: The basic claim to territories, personal preserves, rights to non-distraction-i.e. to freedom of action and freedom from imposition.

- Positive face: The positive consistent self-image or "personality" (crucially including the desire that this self-image be appreciated and approved of ) claimed by others.

Central to Brown and Levinson's theory is the notion of a facethreatening act, an act that risks detriment to speakers' and hearers' face wants: negative face as want for one's actions not to be impeded by others and positive face as want of one's wants to be desirable to others. Particular speech acts are said to impede these wants. For example, orders, requests, suggestions, advice and advice are said to threaten primarily the addressee's negative face want because they potentially indicate that the speaker has no intention to avoid impeding H's freedom of action, in this case by putting some pressure on the hearer to do an act. Other acts are said to be impeding S's wants, e.g. expressing thanks and apologies.

In their elaboration of examples for positive and negative politeness strategies, the emphasis is however very strongly on the effects of acts on the hearer's face. For example, Brown and Levinson's chart of negative politeness strategies (131) emphasizes strategies mitigating face threat to the hearer such as "give H option not to act," "don't coerce H," etc., while positive politeness includes strategies such as "indicate $\mathrm{S}$ knows H's wants and is taking them into account."

The emphasis is, in that respect at least, very strongly on the hearer, yet Brown and Levinson's model is rather speaker-centered, as they describe politeness in terms of speakers' wants and actions rather than hearers' reactions (Arundale 2005). As a consequence, what has been argued for by a number of authors (e.g., Watts 2003; Mills 2003; Locher and Watts 2005) is a distinction of first-order politeness, i.e., on "the ways in which the members of a social group conceptualize (im)politeness as they participate in socio-communicative interaction" (Watts 2003: 27) and secondorder politeness ("the technical term used in the pragmatic and sociolinguistic study of socio-communicative verbal interaction" [Watts 2003: 28]). In this view, politeness is a discursive concept (i.e., negotiated by participants rather than decided about by researchers).

Another criticism that has been brought forward against Brown and Levinson's theory is the emphasis on acts that protect H's face. Goffman had actually gone beyond that, explicitly mentioning aggressive facework 
as a means of "making points". Locher and Watts (2005) also see politeness to be just a small part of what they call relational work, which includes behavior ranging from impolite to over-polite and whose relative value is discursively negotiated.

\subsection{Face, identity and attributes}

We have already seen that in Brown and Levinson's framework, the idea that individuals claim a particular self-image (Goffman) and the notion of personality, which had initially been invoked in the definition of positive face (Brown and Levinson), disappears entirely behind the notion of FTAs. In this section, I take up a line of thought introduced above; namely the relationship of face and identity and the question whether face is projected by speakers and/or negotiated and attributed to them as the result of an encounter. I also describe how self-presentation can be used to draw up a wider theoretical framework for research in interlanguage pragmatics.

Spencer-Oatey has published a number of papers on aspects of face and identity, the most recent of which (Spencer-Oatey 2007) attempts to disentangle the two terms. Most notably, she employs face in her framework of rapport management (Spencer Oatey 2000, 2002).

Spencer-Oatey (2007) argues that, based on Goffman's conceptualization, face entails claims to a wider range of attributes than what is commonly acknowledged, a fact that has been overlooked due to the dominating influence of politeness theory with its distinction of positive and negative face. She agrees with those who see face as an interactional phenomenon- "face entails claims to the evaluations of others" (Spencer-Oatey 2007) - but sees the two terms to be closely related:

In cognitive terms, face and identity are similar in that they both relate to the notion of self-image (including individual, relational and collective construals of self), and both compromise multiple self-aspects or attributes. However, face is only associated with attributes that are affectively sensitive to the claimant. It is associated with positively evaluated attributes that the claimant wants others to acknowledge (explicitly or implicitly), and with negatively evaluated attributes that the claimant wants others NOT to ascribe to him/her. (644)

For Spencer-Oatey, therefore, face only relates to attributes speakers want to be credited with. And just as Goffman, Spencer-Oatey also sees face to be situationally contingent. In her theory of rapport management (Spencer-Oatey 2002: 14), she distinguishes quality face- "a fundamental desire for people to evaluate us positively in terms of our personal qualities, e.g. our competence, abilities, appearance" and identity face-“a 
fundamental desire for people to acknowledge and uphold our social identities or roles, e.g. as group leader, valued customer, close friend," thereby including both personal qualities and social roles into her conception.

For example, a woman may want to foreground a social role as mother in one conversation, or department head in the other conversation. Associated with these roles are then again qualities, e.g. "caring", "soft", "tough", or "persistent" that she may want to be attributed with. Studies on international behavior in workplace encounters have in fact shown that speakers draw on different roles and attributes within a single conversation, depending on the goals they want to achieve (e.g., Holmes 2006).

However, Spencer-Oatey still sees face to be an interactional phenomenon. Although identity aspects are involved in the negotiation of face, speakers are said to claim faces that they want others to acknowledge. Riley (2006) goes beyond that in his paper on self-expression in a foreign language, which reflects Goffman's contention that a self-image is both constructed and projected by speakers and attributed to them.

Central to Riley's framework is the term 'ethos':

Ethos is communicative identity. It is an amalgam of speaker identity (who I am and who I want to be taken for) and perceived identity (who you think I am and who you take me for). It is used by discourse analysts to refer to the self-image projected by a speaker in and through his or her discourse, but also as it is filtered through the hearer's perceptions, expectations and values, especially as constrained by social roles and genres: it is the rhetorical and social-psychological product of mutually influencing communicative behaviours (Riley 2006: 298).

Riley acknowledges the agency of speakers, their desire to construct themselves as certain kinds of people, projected through discourse. How speakers do this can be described by communicative virtues, "socially valued characteristics of discourse [...] (whose) presence [...] contributes to a positive perception of ethos by hearers and to a successful negotiation of identities and outcomes" (Riley 2006: 302).

For Riley, thus, politeness is just one of many communicative virtues, which need to be described in ethnographic accounts of social interaction. He argues that the study of interpersonal behavior needs to move away from what he calls "monocausal" models and from using the term "politeness" to encompass a whole range of different communicative virtues.

With regard to the learning and teaching of foreign languages, Riley further makes the point that, although everybody would agree that foreign languages are learned in order to express oneself, the issue of self- 
Table 1. Communicative virtues (Riley 2006: 302)

\begin{tabular}{lll}
\hline \multicolumn{2}{l}{ Communicative virtues: socially valued characteristics of communication } & \\
attentiveness & enthusiasm & persuasiveness \\
authoritativeness & friendliness & perspicacity \\
charm & fluency & politeness \\
cheerfulness & funniness & relevance \\
clarity & frankness & respectfulness \\
coherence & helpfulness & sensuality \\
competence & honesty & seriousness \\
confidence & integrity & simplicity \\
consistency & intelligence & sincerity \\
conviction & kindness & straightforwardness \\
courteousness & liveliness & sweetness \\
diplomacy & modesty & sympathy \\
discretion & niceness & tactfulness \\
eloquence & open-mindedness & tolerance \\
energy & originality & wittiness \\
\hline
\end{tabular}

expression has not found any in-depth attention in SLA. This is despite the fact that failure to express the desired identity can have major repercussions on how one is perceived: "From the outset, pragmatic failure was a concept that was clearly framed in terms of identity" (Riley 2006: 315). Language learners are in danger of being ascribed identity traits they do not wish to have ascribed to themselves, should they fail to communicate the desired ethos.

\section{Interlanguage Pragmatics}

The study of interlanguage pragmatics is coined by a paradox: On one hand, the word politeness implies very much an evaluative, first-order approach. On the other hand, theoretical frameworks are mostly clearly framed as second-order politeness (e.g., by reference to terms such as positive and negative face). Similarly, analysis is often conducted on a speech-act basis, with analytical frameworks imposed top-down, adopting e.g. the CSSARP framework (Blum-Kulka, House, and Kasper 1989). This does not allow for the discursive perspective on face and politeness described by Locher and Watts (2005). Moreover, definitions of pragmatic competence as the yardstick for the study of pragmatic development are approaching "competence" by way of a set of pre-determined factors. 
Sociopragmatic competence encompasses knowledge of the relationships between communicative action and power, social distance, and the imposition associated with a past or future event (Brown and Levinson, 1987), knowledge of mutual rights and obligations, taboos, and conventional practices $[\ldots]$, or quite generally, the social conditions and consequences, of "what you do, when and to whom' $[\ldots]$. Pragmalinguistic competence comprises the knowledge and ability for use of conventions of means (such as the strategies for realizing speech acts) and conventions of form (such as the linguistic forms implementing speech act strategies [...]. (Kasper and Roever 2005: 317-318)

Pragmatics, however, is commonly defined as more than mere politeness and speech acts, for example by Mey (2001: 6) as "the use of language inhuman communication as determined by the conditions of society." Nevertheless, studies that focus on (a relatively narrow set of ) single speech acts are still dominating the research agenda, as a fairly recent compilation of recent studies on acquisitional pragmatics by Barron (2003: 30-31, 32-34, 59-62) shows. This research generally assumes indirectness and pragmatic routines to be a measure of pragmatic competence, accomplished by internal and external modification, lexical softeners etc. Recent research within this general framework includes Matsumura (2007, 2003), Barron (2003, 2007), Schauer (2004, 2007) and Rose (2000).

There are only a few branches of interlanguage pragmatics which have dared to go beyond this sort of approach. Research on institutional talk is one of them, described as "spontaneous authentic language use by speakers who are speaking as themselves, with socioaffective consequences" (Bardovi-Harlig and Hartford 2005a: 13). Within this general paradigm, Bardovi-Harlig and Hartford (1990, 1993, 1996) investigated the way non-native students engaged in and learned to engage in the talk of academic advising sessions. Furthermore, an edited volume has recently investigated interlanguage pragmatic use and development in different institutional settings (Bardovi-Harlig and Hartford 2005b). The focus is on the question of how learners learn to pursue their personal goals and how they learn to interact within a particular institutional framework.

A further direction, so far pursued only by Siegal (1996) and LoCastro (2001) is subjectivity. Subjectivity is defined by Siegal (1996: 357) as "the construction of self and identity through a second language [...], specifically, learners are 'human subjects with unique histories, goals, and voices, who actively create and recreate their world and themselves" ". In her own study, Siegal found that Mary, a woman from New Zealand, on a trip to Japan, resisted certain sociocultural conventions (use of honorific language, topic control) in order to present herself as a 
knowledgeable researcher who could communicate on equal grounds with a professor.

The point that I want to make is the following: Interlanguage pragmatics would do well to go beyond politeness in the way the term is usually invoked in theroretical frameworks guiding studies on acquisitional pragmatics. Not only is there the danger of statically quantifying and qualifying speech act strategies as evidence for pragmatic development without actually evaluating these strategies against either speakers' or hearer's perceptions and motives, but the term 'politeness' is also limiting by emphasizing the avoidance of face threat rather than the whole range of facework strategies.

I would therefore argue that it is necessary to extent our interest and analysis to other qualities and social role/identities that may be affectively sensitive to a speaker in a particular situation. This can be achieved through a self-presentation framework that explicitly embraces a wide range of attribute and identities. Tracy (1990) delineates self-presentation from facework as follows:

First, while self-presentation occurs in social situations, it is conceived and studied as a one-way phenomenon. Self-presentation largely ignores the fact that social situations involve at last two people. Not only is each person presenting, each person is orienting to the other and presenting how he or she sees the other. Facework, then, includes self-presentation, but also involves other-presentation; stated another way, in involves altercasting (215).

From this perspective, the viewpoint that I am promoting does actually not truly contradict commonly held views of facework as an interactional phenomenon. While I do subscribe to the idea that face is essentially attributed to speakers by others, speakers nevertheless have first say in any face claims they make. Hence, I am arguing for a change of perspective, focusing mainly on speakers and the social roles and qualities they are trying to foreground in a particular encounter.

\section{What to do about binge-drinking: An exemplary analysis of facework strategies in L2 argumentative discourse}

\subsection{Theoretical framework and data}

I now analyze, in an illustrative fashion, one conversation by two L2 learners of German and supplement the analysis with excerpts from a retrospective interview with those learners. Guided mainly by Goffman's (1967) and Spencer-Oatey's $(2000,2002)$ frameworks, I see facework as 
speakers' strategies for self-presentation, including both the social identities or roles and associated qualities speakers want to make relevant during the course of the interaction.

There are a number of possible qualities that speakers might want to have ascribed to themselves when engaged in argumentative discourse, e.g. attentiveness, persuasiveness, authoritativeness, friendliness, perspicacity, fluency, politeness, clarity, coherence, competence, consistency, intelligence, conviction, diplomacy, tactfulness, eloquence, wittiness. Which of these qualities are actually affectively sensitive to learners will however have to be determined by a detailed analysis of the data, as, according to Arundale (2006: 209), "participants' face meanings and actions are conjointly co-constituted as interaction proceeds, it is the participants' interpreting, not the analyst's, that compromise the evidence in studying facework".

Data for the subsequent analysis stem from a larger data corpus for a cross-sectional research project on facework in L2 German development. The subjects were given task instruction cards presenting a problem relating to student life, four different solutions to the problem and a slot to write down a further solution of their own choosing. Subjects were asked to rank these suggestions individually before discussing them in dyads.

Brooke and Ashley are the learners who produced the discussion that is featured in this paper, focusing on the topic "What should the University of X do against binge-drinking in the student population?" Ashley and Brooke were in their first year of a BA Modern Languages degree (joint honors), with proficiency level of approximately level B2 of the Common European Framework. They were well acquainted with each other through their German class. The researcher, who gave students the instructions and set them up in front of a microphone in a language lab, is also leading the weekly 45 -minute oral class the students were taking. She has left the room by the time the conversation starts. After learners had finished their discussion, she returned to conduct a retrospective interview with learners, consisting of a stimulated recall session during which learners were replayed their discussion to them and asked to comment on their thoughts and decision-making processes, and a semi-structured interview.

\subsection{The organization of argumentative sequences}

The way argumentative sequences are organized is the first focus of analysis here. An argumentative sequence is considered to be, for the purpose of this analysis, 
a sequence of turns that are topically related, consisting minimally of a core adjacency pair in which speaker A brings forward an opinion or assessment and in which speaker B reacts to that opinion or assessment. Such an adjacency pair can, but does not necessarily need to be, extended with more turns, relating to the same (sub-topic).

The organization of argumentative sequences is of immediate relevance for self-presentation. By way of presenting, holding onto and defending their own opinions and challenging the opinions of their interlocutors, speakers are able to make social roles and identities relevant in the first place and present themselves as coherent and consistent discussants. In a previous study on L2 German argumentative discourse, using discussions between student learners of German and native speaker professors, Kotthoff (1991) actually observed that the students struggled to convey these qualities. On occasions, learners did not supply answers to proposals made by the native speakers, thus implying that they were accepted. She suggests that this can reflect badly on the speaker, as a missing reaction is equal to admitting that one has not got anything to say.

A related or overlapping concept is that of preference organization, which suggests that, by the way turns are organized, certain actions are invited and oriented to. In argumentative discourse, the organization of turns can betray speakers' stances toward particular opinions as well as their degree of involvement in the discourse, which is again a form of self-presentation. For argumentative discourse, research has shown that, although disagreement is usually brought forward in dispreferred format (e.g., with hesitation, softeners, or postponed) (Pomerantz 1984), very agitated argument can change this format so that disagreement is oriented to as a sign of heightened commitment to the discourse (Kotthoff 1993).

Brooke and Ashley start their discussion by establishing common ground:

\section{Example 1}

$\begin{array}{lll}1 & \text { Ashley: } & \text { alkoho:l ja em: } \\ 2 & \text { Brooke: } & \text { schmeckt gut ja? } \\ 3 & \text { Ashley: } & \text { ja? } \\ 4 & \text { ((beide lachen)) } & \end{array}$

\section{Example 1: Translation}

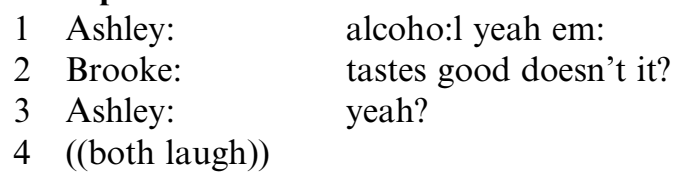


Ashley's short introductory turn features little more than the key word for the discussion-alkohol (1. 1). Brooke takes up this cue and completes the turn (1. 2), the rising intonation and the question tag indicating preference for agreement, but also opening up a space for continuing the turn. This is not taken up by Ashley. Instead, both Ashley and Brook assert their agreement by shared laughter and establish and define themselves as members of a student culture in which alcohol has an important role to play.

It is now Ashley who initiates the next topic:

\section{Example 2}

1 Ashley: ja aber ich denke dass es (.) gefährlich ist wenn man (.) zu 2 viel alkohol getrunken hat?

\section{Example 2: Translation}

1 Ashley: yeah but I think that it (.) is dangerous when one (.) has 2 drunk too much alcohol?

Ashley refers in very general terms to the dangers of alcohol, making an assessment that is as such barely contestable: drinking too much alcohol is dangerous. The hesitations during this turn and the rising intonation at its end nevertheless display a low degree of self-certainty with regard to the assessment, possibly owing to the fact that alcohol plays a big role in the student culture both Ashley and Brooke are part of.

What is also striking is the fact that Ashley's assessment is not subject to any elaboration, e.g., by an extended account of the dangers of alcohol. This is a trend that is continued throughout the discussion, in which both speakers generally only provide further evidence after an initial agreement or disagreement has been established.

\section{Example 3}

1 Brooke: ja: mich auch em (.) ich denke dass wenn man zuviel alkohol

2

3

4

5

6 Brooke: $=$ ehrlich $=$

\section{Example 3: Translation}

1 Brooke: yeah: me too em (.) I think that when one (.) drink- has 2 drunk too much alcohol em then (.) they are not friendly hm: (.) any more

\section{(.) nicht freundlich}

Ashley: ja: aber nur (.) ba: nur manche personen nicht ALLE die personen nicht freundlich sind sind bösen= 
4 Ashley: yeah: but only (.) ba: only some people not ALL of the peo5

6 Brooke: $=$ really $=$

In example 3, which continues the argumentative sequence initiated in example 2, Brooke accounts for Ashley's unsupported claim that drinking too much alcohol is dangerous, suggesting that people misbehave when they have drunk too much (1. 1-3). Even through what is said here is likely to be perfectly supported by common beliefs about alcohol, Brooke seems aware that her suggestion is potentially contentious. After all, the explicit mention of the dangers of alcohol contradicts the consensus that Brooke and Ashley had arrived at in the beginning of the discussion regarding student habits, and it does not make students appear in the best light. Hesitations betray the cautious way she brings this position forward, and the epistemic verb ich denke (1. 1) moves Brooke's argument away from any potential claims to generalizability, thus trying to present herself as cooperative and diplomatic.

This cautious behavior does not lead to agreement with this position, however. Instead, Ashley essentially returns to showing sympathy with the student perspective, proposing that by no means everyone behaves badly when drunk (1. 4-5). The turn shows typical markers of dispreference-possibly in an attempt to display an equal measure of diplomacy-e.g. the token agreement ja aber (1. 4) and nur manche personen (1. 4) as a concession to Brooke.

With a disagreement and a (temporary) difference in opinions now being established (with Brooke arguing that drinking too much alcohol generally leads to people behaving badly and Ashley retorting that this is not always the case) we could, according to the principle of conditional relevance (Schegloff 1968), now expect a further turn by Brooke relating to this issue, a turn in which she either defends her more cautious stance toward alcohol or at least justifies her assessment in some way and relates it to Ashley's assessment. However, such a turn is not forthcoming, and Brooke only comes up with a recipient signal (1. 5). Hence, Brooke does not succeed in displaying consistency by holding on to and defending her opinions. Instead, the lack of a follow-up turn allows Ashley to orient back to the task at hand and start a new argumentative sequence. We are overlooking that sequence for the moment (see example 11) and moving on to a further point in the discussion. 


\section{Example 4}

1 Ashley: =man (.) ich weiß es nicht aber ich werde es ich denke dass

2

7 Ashley: es auch nicht eine gute idee ist em (.) e:h (.) dass alkoholische getränke in den campus bars teurer machen

Brooke: ja: ich denke dass ich em (.) persönlich könnte nicht em mehr bezahlen für [getränke aber vielleicht das ist gut weil em manchmal trinke ich $=$

8 Brooke: =zu viele und dann an die nächs- die nächste tag bin ich

12 Ashley: $=$ du hast kopfschmerzen=

13 Brooke: $=j a=$

14 Ashley: =und magenschmerzen

15 Brooke: und ich em habe menschen (.) insultieren ((nickt, rollt mit den Augen))

\section{Example 4: Translation}

1 Ashley: $=$ one (.) I don't know but I will I think that it is also not a

7 Ashley: good idea is em (.) e:h (.) that alcoholic drinks in campus bars are made more expensive

Brooke: yeah: I think that I em (.) personally would not be able to em pay more for [drinks but perhaps this is good because em sometimes I drink $=$

8

12 Ashley: =you have a headache $=$

13 Brooke: =yeah=

14 Ashley: =and a tummyache

15 Brooke: and I em have insulted (.) people ((nods, rolls 16

$$
\text { her eyes)) }
$$

Here, Ashley initiates a sequence by expressing her stance toward one of the suggestions made on the task instruction cards: making alcoholic drinks in campus bars more expensive, an idea which she rejects without providing any reason or evidence (1. 1-3). In the answer that now becomes relevant, Brooke partially agrees with Ashley, suggesting that she would personally not be able to pay higher prices for alcoholic drinks, 
but that the proposal as such may be useful because she herself sometimes drinks too much (1. 4-5, 1. 8-9).

It is this turn that Brooke comments on in some detail in the retrospective interviews:

\section{Example 5 (retrospective interview):}

Brooke: I knew I wanted to say I wouldn't be able to afford it and (I wanted to say) 'Ich kann' but I realized that was like in the present tense or whatever so I changed to 'ich könnte' as in 'I would be able to', 'Ich könnte nicht'. But then I thought well this is like personally seen as it might not apply to everybody but it is probably good. And I wanted to say that I kind of agreed with her point of view but I wouldn't be able to afford it but then afterwards decided that maybe that is a good thing because sometimes I drink too much. So that's it.

What is becoming clear here is that Brooke is mainly concerned with making sure that she is being seen as a person who is ready to compromise and to accept other points of view. Hence, she uses a partial concession to make Ashley see that she has sympathies for her opinion, although she is not in total agreement with it.

Nevertheless, given that difference of opinion established in the two initial (core) turns of the argumentative sequence, we would now expect Ashley to come up with a reply to Brooke's turn; not necessarily fierce disagreement, but at least some form of justification for her position. However, Brooke had ended her turn with signs of linguistic insecurity (hesitation, rising intonation, seeking eye contact-see 1. 7-8). As a consequence, Ashley chooses to use Brooke's linguistic problems for linguistic scaffolding $(1.11,1.13)$ rather than a reply to the actual argument brought forward by Brooke. By offering such assistance, she essentially breaks out of the frame of the argument into the frame of a language task that has to be completed competently.

Brooke takes up this alignment by adding an example of her own (1. 14), which causes a contradiction to arise between what had been originally proposed (making alcoholic drinks more expensive is not a good idea) and the outcome of the sequence (drinking too much causes all kinds of problems), an outcome which is not the result of reasoned argument. However, despite the problems in displaying qualities relevant to argumentative discourse such as consistency and perseverance, selfpresentation appears to be happening on entirely different level that stands in no direct relationship to the argument itself. Ashley for example presents herself as helpful peer, allowing Brooke to display an image of 
competence as learner and speaker of German. Although no comments are available on this particular part of the argument, the semi-structured interview points to this (see 5).

\subsection{Markers of reference and identity}

The second main area of analysis is markers of reference and identity used by speakers. How do they refer to themselves and others? Do they associate or disassociate themselves from particular groups? The following example represents the end of the argumentative sequence from example 5:

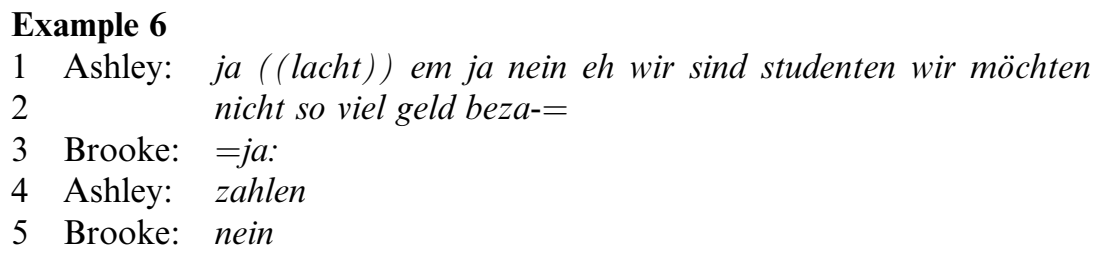

\section{Example 6: Translation}

1 Ashley: yeah ((laughs)) em yeah no eh we are students we don't 2 want to pay that much mon-=

3 Brooke: =yeah:

4 Ashley: money

5 Brooke: no

In this final turn of the sequence, Ashley seeks realignment with what she had originally proposed, namely that she is against making alcoholic drinks in campus bars more expensive. The first person plural pronoun wir (1. 1) and studenten (1. 1) are an expression of group membership and projection as young, fun-loving student.

This is however not the only role alignment taken up in the course of this discussion. Although the two discussants are both students who can very much "be themselves" in the conversation, it nevertheless takes place in the public space of an educational institution and under the constraints of societal ostracism of alcohol-related (mis-)behaviors. This background considered, generic markers of reference (man, sie) allow Brooke to distance herself from those she talks about and those said to display the behaviors mentioned-drinking too much alcohol and misbehaving as a result of it: 


\section{Example 7}

1 Brooke: ja: mich auch em (.) ich denke dass wenn man zuviel alkohol em (.) trink-getrunken hat em dann (.) sie sind mehr hm: (.) nicht freundlich

\section{Example 7: Translation}

1 Brooke: yeah: me too em (.) I think that when one (.) drink- has 2 drunk too much alcohol em then (.) they are not friendly 3 hm: (.) any more

Markers of identity and reference can be strong enough to indicate a stand without making that opinion explicit:

\section{Example 8}

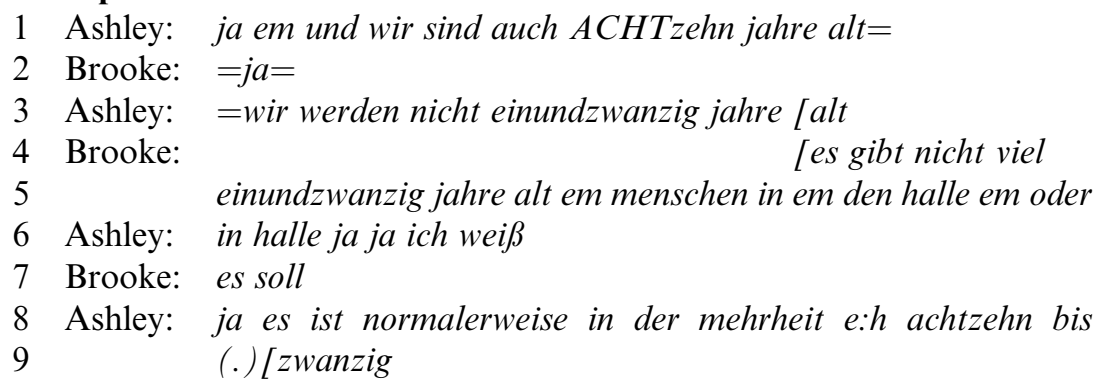

\section{Example 8: Translation}

1 Ashley: yeah em and we also are EIGHTeen years old=

2 Brooke: $=$ yeah $=$

3 Ashley: =we will not be twenty-one years [old

4 Brooke: [there aren't many

5 twenty-one year old em people in em halls are there

6 Ashley: in halls yeah yeah I know

7 Brooke: there should ....

8 Ashley: yeah it is usually in the majority e:h eighteen to

$9 \quad$ (.)[twenty

In this sequence, the personal pronoun wir $(1.1,3)$ indicates Ashley's dismissive stance towards the suggestion from the task instruction cards of making alcohol available only to people who are more than twenty-one years old. In addition, Ashley is able to immediately include Brooke in the rejection of age restrictions. Furthermore, there is repeated emphasis on the typical age of students $(1.1,3,8,9)$. At no time do either Ashley or Brooke evaluate or assess the suggestion from the task cards explicitly, namely that alcohol should only be sold to students over twenty-one years 
of age. Instead, these markers of group identity or membership are strong enough contextualization cues to signal alignment with their identity or social role as students and therefore a strategy for self-presentation.

This is confirmed in Ashley's retrospective comment:

\section{Example 9 (retrospective interview):}

Ashley: Well I was sort of trying to say how it's eh student it's the student lifestyle and then Jane came up with the point that there is not many twentyone year olds.

Brooke: Yeah I think we were kind of reading off the sheet and we were trying to the conversation was kind of stopping so we were trying to come up with a new point so.

In this retrospective comment, Brooke brings up another aspect of selfpresentation that appears to have been important to herself and potentially her partner. She suggests that fluency and a consistent word-flow were issues of some concern. This is again confirmed later during the semi-structured interview (see 5).

\subsection{Epistemic Modality}

In this section of the analysis, I am mainly concerned with epistemic modality as one instantiation of modality. Consider example 10:

\section{Example 10}

1 Brooke: vielleicht em sollten eh sollen die campusbar nur am 2

3 Ashley: $=j a !=$

4 Brooke: =und dann weil em oft menschen em jede nacht [trinken und 5

6 Ashley: dann $=$

7 Brooke: =das ist nicht gut für ihre gesunde und es nicht nicht gut 8 wenn (.) sie em (.) dürfe dinge machen und

\section{Example 10: Translation}

1 Brooke: perhaps em should eh the campus bar should only be open 2 on the weekend=

3 Ashley: =yeah!=

4 Brooke: =and then because em often people em drink every [night 5

6 Ashley: then this $=$

7 Brooke: =is not good for their health and it is not good if (.) they em (.) can do things and 
When introducing her suggestion that campus bars open only at the weekend, Brooke uses two means of modalization: the modal verb sollen (1. 1) - first in the conditional and then in the simple form - and the downgrader vielleicht (1. 1). The desired effect of these devices is to mitigate and tone down the suggestion in order to weaken its potential impact on the addressee. Brooke can present herself a person who is polite and potentially ready for compromise, while retaining the authority to bring forward a new proposal.

Nuyts (2001) defines epistemic modality as follows:

Epistemic modality concerns an estimation of the likelihood that (some aspect of) a certain state of affairs is/has been/will be true (or false) in the context of the possible world under consideration. And this estimation of likelihood is situated on a scale [...] going from certainty that the state of affairs applies, via a neutral or agnostic stance towards its occurrence, to certainty that it does not apply, with intermediary positions on the positive and the negative sides of the scale. (22)

In the context of argumentative discourse, markers of epistemic modality are of prime relevance as they allow speakers to indicate their degree of commitment to a proposition. Nevertheless, as a whole, the discussion features only a small number of markers of epistemic modality in a similar, downgrading function. In addition to two instances of vielleicht and a number of instances of ich weiß (es) nicht, epistemic verbs such as ich denke occur frequently:

\section{Example 11}

1 Ashley: ja (.) ja ich denke dass alkohol ein

3 Brooke:

8 Brooke: =dann ich denke dass das nicht gut ist

9 Ashley: ja aber (.) wie können man das (sagen) wenn man

$10 \quad$ [zu viel alkohol $=$

11 Brooke: [ja (.) ja

12 Ashley: =getrunken hat man hm: (.) man muss nicht man muss

grosses teil eh [des studentleben ist

[ja (.) ja das stimmt

(.) aber ich denke dass em (.) in eh campusbars em sie verkaufen alkohol wenn jemand em schon zu viel getrunken hat [ich glaube und $=$ man sollen ich weiß es nicht (.) nein ich denke es war hm es würde zu hart sein=

Brooke: $=h m=$

Ashley: $=e m=$

Brooke: $=h m=$ 


\section{Example 11: Translation}

1 Ashley: yeah (.) yeah I think that alcohol is a big part eh

2

3 Brooke:

8 Brooke: =and then I think that this is not good

9 Ashley: yeah but (.) how can one (say) that one has drunk

10

11 Brooke: [yeah (.) yeah

12 Ashley: =alcohol hm: (.) one must not one must one shall I don't know (.) no I think it was hm it would be too hard=

17 Brooke: $=\mathrm{hm}=$

In this argumentative sequence, Ashley and Brooke are discussing the responsibility of campus bars toward students. While Ashley starts off by again asserting a student identity (1. 1), Brooke responds by claiming that campus bars do not take their responsibility seriously and keep selling drinks to the although students may have already drunk too much $(1.3-5,7)$, an assessment which is softened and postponed by a short agreement formula (1.3-4).

Ashley objects to this on grounds that it is impossible to say when somebody has been drinking too much, an objection which is again softened by token agreement $(1.9,12-14)$. Further within this objection turn, Ashley attempts to bring forward what sounds like the start of a proposal (man muss nicht man muss man sollen [1.12]). She is however, most likely owing to language difficulties, stopped in her tracks, and eventually reverts to the implicit evaluative phrase es würde zu hart sein (1.14).

The phrase ich weiß nicht, which stands between the modal verbs and that evaluative phrase, can be interpreted in two different ways. Firstly, it is a downgrader, allowing Ashley to lower her commitment to what she is saying by claiming ignorance. Secondly, it concludes the unsuccessful attempt at a suggestion and initiates, after a pause, a new unit in the turn with the evaluative phrase. Hence, the device structures the ensuing discourse, and allows Ashley more thinking time.

This interpretation cannot be directly confirmed from Ashley's and Brooke's retrospective comments. However, in the retrospective inter- 
view, both mentioned accuracy and fluency as affectively sensitive aspects of self-presentation:

\section{Example 12 (retrospective interview):}

Ashley: Probably that I didn't know how to say it in Engl- in German. I wanted to say something in German but I didn't know what it was so I had to sort of change it switch it around so I (could get away with it).

Brooke: I couldn't find the right adjective in German so I spent the whole time saying nicht gut because I couldn't think of anything else to say I think that's wrong something like that so I kept saying I think that's not good.

Ashley: And I kept saying Ich denke dass es ein gute idee ist.

While Ashley makes reference to her concerns for accuracy and her ability to get the conversation going, both speakers mention the fact that they used formulaic and easily accessible phrases such as nicht gut or eine gute idee to that effect. In the context of their appearance, devices such as ich wei $\beta$ nicht appear to be of a similar nature and thus, can fulfill similar functions, as shown in the analysis of example 11.

Instances of epistemic verbs such as ich denke or ich glaube can also be interpreted in this way, as they tend to occur at transition points (e.g. after abandoned sentence parts) and replace linking devices such as conjunctions or help launch a speaker into a turn (see 1. 1, 4, 5, 7, 12). Although they are still markers of epistemic modality-House and Kasper (1981) describe them as "minus committers"- they fulfill a dual function as discourse-structuring devices and aids to processing for Brooke and Ashley. It may be for this reason that downgraders, albeit not very frequent overall, yet occur far more often than upgraders, which could add authority and conviction to a claim or function.

A single upgrader occurs in the final part of the conversation:

\section{Example 13}

1 Brooke: ja: i- ich denke auch dass em trinke die cocktails und alco-

2

3

4

5

6 Ashley: $=j a=$

7 Brooke: =in dieser trinken ist aber getränk ist

8 Ashley: ja em: kampf- (.) kampftrinken ist NATÜRLICH nicht

$9 \quad$ eine gute idee aber hm: jede studenten=

10 Brooke: =sind immer $($ trunken $)=$ 
11 Ashley: em [ja:

12 Brooke: [immer zuviel getrunken=

13 Ashley: =ja:

14 Brooke: und

15 Ashley: ja: (.) aber nicht zuviel

16 Brooke: nicht zuviel weil em man muß über

17 Ashley: nicht jede nacht ((lacht))

18 Brooke: man (.) man muß über (.) seine gesund denken weil es

19 Ashley: ja:

20 Brooke: nicht gut für dein [(.) ist

21 Ashley: [ja: aber ich denke dass universiTäT nicht gut für gesundheit ist

22 Brooke: nei:n nei:n gen- eh das stimmt!

\section{Example 13: Translation}

1 Brooke: yes I- I also think that em drinking cocktails and alcopops

112 Ashley: em [yes:

12 Brooke: [always drunk too much $=$

13 Ashley: =yes:

14 Brooke: and

15 Ashley: yeah: (.) but not too much

16 Brooke: not too much because em one must about

17 Ashley: not every night ((laughs))

18 Brooke: one (.) one has to about (.) think about one's health

19 Ashley: yeah:

20 Brooke: because it is not good for [(.) your

21 Ashley:

[yes: but I think that universiTY is not good for your health

22 Brooke: no: no: exa- eh that's right!

While Brooke asserts her generally more cautious stance toward alcohol $(1.1-4,1.7)$, Ashley aligns herself more closely with being a fun-loving 
student who knows about the dangers of alcohol, but yet is aware of the realities of being a student. The upgrader natürlich (1. 8), which is also prosodically emphasized, sharpens the contrast between Ashley's concession to Brooke and the forthcoming objection on grounds that it is normal to drink too much as a student.

At the end of this sequence, which also concludes the discussion as a whole, Ashley and Brooke use humor to juggle the dual social group alignment that has been apparent throughout the discussion (young, funloving student vs. responsible adult), arguing that university life generally is not good for one's health, alcohol aside.

\section{Discussion}

In this paper, I illustrated by analyzing an argumentative conversation by two L2 learners of German, that current conceptualizations of face and facework in interlanguage pragmatics are not sufficient to account for speakers' strategies throughout the discussion. I have argued that therefore, a new perspective on interlanguage pragmatic data is necessary, which proposes that it is important to focus the analyst's attention onto aspects of discourse beyond linguistic politeness, namely strategies which the speaker may use for self-presentation in a particular encounter.

Ashley and Brooke perform self-presentation in two main areas. On the level of the actual argumentative discourse, their social role alignment is represented by the identities they are trying to make relevant through their engagement in the discussion. We have seen that they are quite competently balancing conflicting roles - on one hand, a self-image as "young, fun-loving student" with a relaxed attitude toward alcohol, and on the other hand an identity as "responsible adult" who is aware of the dangers of alcohol - through a variety of markers of identity and reference.

Associated with that engagement are three main quality sets, which vary with regard to the extent to which they are affectively sensitive to Ashley and Brooke (table 2).

Originally, this research had been set up in quite a polarized way, with the researcher wanting to extrapolate extended argument. However, this analysis of this discussion shows that Brooke and Ashley, having acted out their discussion in the safe environment of a language lab with little or no implications for their real lives, did not construe of the discussion in that manner. They were however clearly aware that qualities such as assertiveness and persuasiveness are potentially relevant qualities in argumentative discourse. Asked whether they might have argued in a different 
Table 2. Self-presentation and linguistic realization

\begin{tabular}{lc}
\hline self-presentation & linguistic realization \\
\hline $\begin{array}{c}\text { social role alignment 1: young, fun-loving } \\
\text { student, responsible adult,... }\end{array}$ & $\begin{array}{c}\text { markers of identity and reference, turn } \\
\text { choice and sequencing }\end{array}$ \\
- quality set 1: coherence, consistency & turn sequencing \\
- quality set 2: authority, persuasiveness, & markers of epistemic modality, evidence, \\
assertiveness & turn organization \\
- quality set 3: diplomacy, tactfulness, & markers of epistemic modality, concession / \\
politeness, cooperation & partial agreement, turn organization \\
social role alignment 2: L2 speaker & \\
- quality set 4: accuracy, fluency & markers of epistemic modality as aids to \\
& processing, word replacement, topic \\
- quality set 5: helpfulness & abandonment \\
\hline
\end{tabular}

style if they had done the discussion in their mother tongue, they answered the following:

\section{Example 14 (retrospective interview):}

Ashley: Yeah it would have definitely been as I said more assertive.

Brooke: I think maybe we would contradict one another more often just because we could (state the opposite) whereas we can't do that in German just because it just makes it more complicated.

Ashley: It would have been much more complex as well.

Efforts to convey qualities such as assertiveness (mainly quality set 2) appear to have been overridden by the second main role alignment - that of L2 speaker-with the associated qualities of accuracy and fluency (or mutual helpfulness). Self-presentation on that level is made possible by avoiding complication and complexity, e.g. through abandonment of topics, the use of markers of epistemic modality as processing aids etc. Indeed, when asked whether, at any point, they had considered linguistic alternatives to what they actually said, Ashley suggested that this happened "because I didn't know how to construct it in German", but did not mention other possible reasons such as conveying an image of cooperativeness or assertiveness (i.e. quality sets 1-3).

Throughout the discussion, Ashley and Brooke certainly did attend to qualities such as diplomacy, tactfulness and politeness (quality set 3 ), although possibly not at all times consciously. Nevertheless, Ashley and Brooke quite successfully used linguistic strategies such as partial 
agreement/concession before disagreement, and also a limited range of downgraders to mitigate their opinions.

As for qualities such as assertiveness, authority, persuasiveness (quality set 2) and coherence and consistency in argument (quality set 1), these were, as I have already shown, not particularly affectively sensitive to Ashley and Brooke. From an outsider's perspective, they are also not particularly successful in conveying these qualities. While they used very few upgraders, there are a large amount of pauses, hesitations and repairs as a result of word search and linguistic difficulties. Moreover, topics tended to be dropped very quickly and not elaborated on, and opinions were rarely supported by evidence.

However, even though those qualities may not be relevant to the speakers themselves, they may still be relevant to others. In particular in "real life" situations outside the classroom environment, non-native speakers' discourse is regularly subject to scrutiny by others. It is therefore vital to ask not only what qualities and social roles speakers may want to convey, but also what other participants in an encounter may want to see conveyed, and to what extent there may be intercultural differences regarding the assessment of these roles and qualities. Analyses of intercultural encounters have of course revealed that participants' evaluations of what is important in a particular encounter can differ to a great extent (Spencer-Oatey and Xing 2003) across situations and cultures.

Hence, pedagogy of L2 self-presentation in oral discourse needs to link their teaching to the genres and discourse types in which the selfpresentation happens. Although the language classroom can never completely simulate real-life situations, efforts can still be made and steps taken to equip learners with the linguistic resources appropriate to the discourse types they regularly participate in (or may do so in the future) in the target culture, allowing them project a self-image which they want or need to be attributed with. Applying a self-presentation framework to research in interlanguage pragmatics could provide the necessary groundwork for this.

\section{Conclusion}

In the past, a number of prominent researchers in the field of interlanguage pragmatics have commented on the lack studies on L2 pragmatic development as compared to those on L2 use, e.g., Bardovi-Harlig (1999: 679): "Not only was interlanguage pragmatics not fundamentally acquisitional, but it was [...] fundamentally not acquisitional". The field 
now seems to have recognized this gap and is trying to catch up to other fields of SLA by studying acquisition and development.

This paper has proposed that the field of interlanguage pragmatics is ready for further changes, starting with a renewed theoretical perspective on face, and leading to new objects of research. If face and facework were seen as efforts for presentation self-presentation beyond politeness, interlanguage pragmatics could significantly enlarge its research agenda.

\section{Acknowledgments}

I would like to thank the anonymous reviewers for their very helpful comments on an earlier draft of this paper, in particular its theoretical foundations.

\section{References}

Arundale, Robert (2005). Face as relational and interactional: Alternative bases for research on face, facework and politeness. Paper presented at the 9th International Pragmatics Association Conference. July 10-15.

Arundale, Robert (2006). Face as relational and interactional: A communication framework for research on face, facework and politeness. Journal of Politeness Research 2: 193-216.

Barron, Anne (2003). Acquisition in Interlanguage Pragmatics: Learning How to Do Things With Words in a Study Abroad Context. Amsterdam: John Benjamins.

Barron, Anne (2007). "Ah no honestly we're okay:" Learning to upgrade in a study abroad context. Intercultural Pragmatics 4(2): 129-166.

Bardovi-Harlig, Kathleen (1999). Exploring the interlanguage of interlanguage pragmatics: A research agenda for acquisitional pragmatics. Language Learning 49(4): 677-713.

Bardovi-Harlig, Kathleen and Berverly Hartford (1990). Congruence in native and nonnative conversations: Status balance in the academic advising session. Language Learning 40(4): 467-501.

Bardovi-Harlig, Kathleen and Berverly Hartford (1993). Learning the rules of academic talk: A longitudinal study of pragmatic change. Studies in Second Language Acquisition 15(3): 279-304.

Bardovi-Harlig, Kathleen and Beverly Hartford (1996). Input in an institutional setting. Studies in Second Language Acquisition 18(2): 171-188.

Bardovi-Harlig, Kathleen and Beverly Hartford (2005a). Institutional discourse and interlanguage pragmatics research. In Interlanguage Pragmatics: Exploring Institutional Talk. Bardovi-Harlig, Kathleen and Beverly Hartford (eds.), 7-36. Mahwah: Lawrence Erlbaum.

Bardovi-Harlig, Kathleen and Beverly Hartford (2005b). Interlanguage Pragmatics: Exploring Institutional Talk. Mahwah: Lawrence Erlbaum.

Beebe, Leslie (1995). Polite fictions: Instrumental rudeness as pragmatic competence. In Linguistics and the Education of Language Teachers: Ethnolinguistic, Psycholinguistic and Sociolinguistic Perspectives. James Alatis, Carolyn Straehle, Brent Gallenberger and Maggie Ronkin (eds.), 154-168. Washington: Georgetown University Press. 
Blum-Kulka, Susanna, Juliane House, and Gabriele Kasper (1989). Cross-Cultural Pragmatics: Requests and Apologies. Norwood: Ablex.

Brown, Penelope, and Stephen Levinson (1987). Politeness: Some Universals in Language usage. Cambridge: Cambridge University Press.

Culpeper, Jonathan (1996). Towards an anatomy of impoliteness. Journal of Pragmatics 25: 349-67.

Culpeper, Jonathan, Derek Bousfield and Anne Wichmann (2003). Impoliteness revisited: with special reference to dynamic and prosodic aspects. Journal of Pragmatics 35(10-11): $1545-1579$.

Goffman, Erving (1967). Interaction Ritual: Essays on Face-to-Face Behavior. New York: Pantheon Books.

Holmes, Janet (2006). Gendered Talk at Work. Malden: Blackwell.

House, Juliane and Gabriele Kasper (1981). Politeness markers in English and German. In Conversational Routine: Explorations in Standardized Communication Situations and Prepatterned Speech. Florian Coulmas (ed.), 157-185. The Hague: Mouton Publishers.

Harris, Sandra (2001). Being politically impolite: extending politeness theory to adversarial political discourse. Discourse and Society 12: 451-472.

Kasper, Gabriele and Carsten Roever (2005). Pragmatics in second language learning. In Handbook of Research in Second Language Teaching and Learning. Elli Hinkel (ed.), 317-333. Mahwah: Lawrence Erlbaum.

Kienpointner, Manfred (1997). Varieties of rudeness: Types and functions of impolite utterances. Functions of Language 4(2): 251-287.

Kotthoff, Helga (1991). Lernersprachliche und interkulturelle Ursachen für kommunikative Irritationen: Zugeständnisse und Dissens in deutschen, anglo-amerikanischen und nativnichtnativen Gesprächen. Linguistische Berichte 135: 375-397.

Kotthoff, Helga (1993). Disagreement and concession in disputes: On the context sensitivity of preference structures. Language in Society 22: 193-216.

LoCastro, Virginia (2001). Individual differences in second language acquisition: Attitudes, learner subjectivity, and L2 pragmatic norms. System 29(1): 69-89.

Locher, Miriam and Richard Watts (2005). Politeness theory and relational work. Journal of Politeness Research 1(1): 9-33.

Matsumura, Shoichi (2003). Modelling the relationships among interlanguage pragmatic development, L2 proficiency, and exposure to L2. Applied Linguistics 24(4): 465-491.

Matsumura, Shoichi (2007). Exploring the aftereffects of study abroad in interlanguage pragmatic development. Intercultural Pragmatics 4(2): 167-192.

Mey, Jacob (2001). Pragmatics: An Introduction. Oxford: Blackwell, 2001.

Mills, Sara (2003). Gender and Politeness. Cambridge: Cambridge University Press.

Nuyts, Jan (2001). Epistemic Modality, Language, and Conceptualization: A CognitivePragmatic Perspective. Amsterdam: John Benjamins.

Pomerantz, Anita (1984). Agreeing and disagreeing with assessments: Some features of preferred/dispreferred turn shapes. In Structures of Social Action: Studies in Conversation Analysis. J. Maxwell Atkinson and John Heritage (eds.), 57-103. Cambridge: Cambridge University Press.

Riley, Philip (2006). Self-expression and the negotiation of identity in a foreign language. International Journal of Applied Linguistics 16(3): 295-318.

Rose, Kenneth (2000). An exploratory cross-sectional study of interlanguage pragmatic development. Studies in Second Language Acquisition 22(1): 27-67.

Schauer, Gila (2004). May you speak louder maybe? Interlanguage pragmatic development in requests. In EUROSLA Yearbook (Vol. 4). 253-272. Amsterdam: John Benjamins. 
Schauer, Gila (2007). Finding the right words in the study abroad context: The development of German learners' use of external modifiers in English. Intercultural Pragmatics 4(2): $193-220$.

Schegloff, Emanuel (1968). Sequencing in conversational openings. American Anthropologist 70(6): 1075-1095.

Spencer-Oatey, Helen (2000). Rapport management: A framework for analysis. In Culturally Speaking: Managing Rapport Through Talk Across Cultures. Helen Spencer-Oatey (ed.), 11-45. London: Continuum.

Spencer-Oatey, Helen (2002). Managing rapport in talk: Using rapport sensitive incidents to explore the motivational concerns underlying the management of relations. Journal of Pragmatics 34: 529-545.

Spencer-Oatey, Helen (2007). Theories of identity and the analysis of face. Journal of Pragmatics 39: 639-656.

Spencer-Oatey, Helen and Jianyu Xing (2003). Managing rapport in intercultural business interactions: a comparison of two Chinese-British welcome meetings. Journal of Intercultural Studies 24(1): 33-46.

Siegal, Mary (1996). The role of learner subjectivity in second language sociolinguistic competency: Western women learning Japanese. Applied Linguistics 17(3): 356-382.

Tracy, Karen (1990). The Many Faces of Facework. In Howard Giles and W. Peter Robinson (eds.), Handbook of Language and Social Psychology. 209-226. Chichester.

Watts, Richard (2003). Politeness. Cambridge: Cambridge University Press.

\section{Appendix:}

Transcript Conventions

\begin{tabular}{|c|c|}
\hline .) & pause \\
\hline em, eh & hesitation markers \\
\hline but- & false starts and abrupt cut-offs \\
\hline & rising intonation \\
\hline ! & very animated tone \\
\hline CAPITALS & extremely stressed utterance \\
\hline vord) & $\begin{array}{l}\text { utterance not clearly intelligible; transcriptioners' best } \\
\text { guess }\end{array}$ \\
\hline & elongation of an utterance \\
\hline (comment)) & $\begin{array}{l}\text { some sound or feature of the talk that cannot be very eas- } \\
\text { ily transcribed, e.g. laughing, coughing }\end{array}$ \\
\hline & $\begin{array}{l}\text { latched turns and turns by the same speaker that are over- } \\
\text { lapping lines }\end{array}$ \\
\hline & simultaneous/overlapping utterances \\
\hline ) & utterance unintelligible \\
\hline
\end{tabular}

